\title{
Building confidence in STEM students through breaking (unseen) barriers
}

\author{
Philip J. Heron ${ }^{1}$ and Jamie A. Williams ${ }^{2}$ \\ ${ }^{1}$ University of Toronto Scarborough, Dept of Physical and Environmental Sciences, Toronto ON, Canada \\ ${ }^{2}$ Spectrum First Education, Leeds, UK
}

Correspondence: Philip J. Heron (philip.heron@utoronto.ca)

\begin{abstract}
.
Science, technology, engineering, and math (STEM) subjects have historically struggled to be inclusive and accessible to students from diverse backgrounds. The field of geoscience, in particular, has also had challenges in diversity with respect to staff and student recruitment. The consequence of non-inclusive practices still propagates today, with certain demographics not engaging in STEM activities. As a result, there needs to be conscious efforts to adopt equity, diversity, and inclusive (EDI) initiatives for subjects such as geoscience to grow. In this article, we outline the steps we have taken to break down known (and unknown) barriers to education in the teaching of a science outreach course to a diverse student body. Our outreach course, Think Like A Scientist, has been running in a number of UK prisons since 2019. Although the program is tailored to the restrictive prison environment, the application of its core principles to education are fundamental EDI practises that could be beneficial to a wide audience. In this paper, we outline our reasoning for specific pedagogical choices in the classroom when working with students that have low confidence in STEM education, and highlight the need for engagement that is relatable, accessible, inclusive, and offers encouragement.
\end{abstract}

\section{Introduction}

A student's low confidence in their own ability can lead to non-engagement in the classroom (Angus et al., 2008; Legault et al., 2006; Statistics Canada, 2002). In particular, science, technology, engineering, and math (STEM) subjects have shown to generate negativity amongst students (Holmes et al., 2018), with the reasons behind such low confidence being multi-factorial. For instance, critical educational neuropsychological research (Billington, 2017; Damasio, 2000) has indicated how social, emotional, and cultural factors impacting disadvantaged students cannot be separated from a student's cognitive ability to learn within formal environments. Furthermore, research suggests that students who believe themselves not to 'fit' into educational settings are more likely to perform poorly or withdraw, due to the impression they do not match the profile of students who usually succeed (e.g., 'stereotype threat', Steele and Aronson (1995); Pennington et al. (2016)). This can be due to feelings of stigma (or 'minority stress', Meyer (1995); Parker and Jones (1999)) that relate to race, religion, disability, economic status, sexuality, gender, or other intersecting cultural factors (Dowey et al., 2021). This stigma can also be subtly reinforced in the language and hierarchies used in STEM classroom settings. 

course in UK prisons in 2019 (Heron, 2019, 2020). The course, called 'Think Like A Scientist', was designed to improve critical thinking and encourage independent thought for students. The program, the first of its kind in England, used short, impactful talks on science topics to bring new information to the class (where a number of subjects were geoscience focused, such as climate change, plate tectonics, natural hazards, and space missions). Students participated in seven different 2.5 hour sessions and were encouraged to do assignments each week.

For prison learning, education and employment have been highlighted by the UK Government's Ministry of Justice as key points in reducing re-offending rates (Coates, 2016). However, due to restrictive prison environments (Rogers et al., 2014; O'Brien et al., 2021), a lack of funding for prison educational programs, and (most importantly) the impact of prisoners' previous struggles with traditional classroom settings, teaching in prison is a complex endeavour. As such, educational needs are largely unmet for those in custody (Geib et al., 2011).

To overcome these obstacles, a key component of our teaching in prison was to align education to the needs of students that are harder to reach, rather than students adapting to the pace and structure of an inflexible education program (von Stumm and Wertz, 2021). As a result, the focus of our course was to act as a stepping-stone to more formal education (e.g., high school diplomas and undergraduate courses) through increasing confidence in the student's abilities in the short and long-term. The method we implemented follows that course content be relatable, accessible, inclusive, and offer encouragement (RAIE method).

\section{Relatable}

By visiting successful prison education programs during the development of our course, it was clear that learners engaged best when the material was relatable (e.g., classes related to criminology and law) (King et al., 2018). This posed a challenge for more abstract STEM fields, that appeared to be far from normal day-to-day life. Furthermore, as mentioned above regarding 'stereotype threat' (Steele and Aronson, 1995; Pennington et al., 2016), potential students also may find the scientists themselves difficult to relate to (e.g., coming from a 'ivory tower').

Although some of the course had material that is directly applicable to every day life (e.g., sleep and climate change), the majority of topics taught were not immediately relatable (e.g., space missions to Mars, earthquakes, robotics, the universe).

50 However, to bridge the gap between student and STEM content, the course focused on how we think about a subject - a process which is inherently relatable. Instead of a standard passage of information from teacher to student, our course taught the 'the scientific method' (Figure 1) as a framework where students explore what they do not know about a subject and discuss how we can find out more. This method has been shown to improving critical thinking among students (Davenport Huyer et al., 2020).

For instance, each session starts by asking the group to list anything related to the main topic (e.g., what do we know about the solar system?). From here we can understand the key areas to focus on and ask how we can find that out (e.g., Do we need to visit Mars to check for life? Can we send robots? What would they look like? How would they work?). 


\begin{tabular}{|c|c|c|c|}
\hline The Scientific Method & Level 1 & Level 2 & Level 3 \\
\hline Step 1: Ask a question? & $\begin{array}{l}\text { 1. Why does the light } \\
\text { not turn on? }\end{array}$ & $\begin{array}{l}\text { 1. What can improve } \\
\text { my mood? }\end{array}$ & $\begin{array}{l}\text { 1. Is fracking good or } \\
\text { bad? }\end{array}$ \\
\hline Step 2: Construct a hypothesis & $\begin{array}{l}\text { 2. Has the lightbulb } \\
\text { burnt out? }\end{array}$ & $\begin{array}{l}\text { 2. Sleep could play a } \\
\text { role }\end{array}$ & $\begin{array}{l}\text { 2. Fracking is bad } \\
\text { overall }\end{array}$ \\
\hline Step 3: Conduct experiments & 3. Replace lightbulb & $\begin{array}{l}\text { 3. Keep a mood and } \\
\text { sleep diary }\end{array}$ & $\begin{array}{l}\text { 3. Research good } \\
\text { points and bad points }\end{array}$ \\
\hline $\begin{array}{l}\text { Step 4: Understanding } \\
\text { Step 5: Analysis }\end{array}$ & $\begin{array}{l}\text { 4. Has that fixed the } \\
\text { problem? }\end{array}$ & $\begin{array}{l}\text { 4. What impact am I } \\
\text { looking for? }\end{array}$ & $\begin{array}{l}\text { 4. Which points are } \\
\text { most important and } \\
\text { why? }\end{array}$ \\
\hline$\Rightarrow$ il $\begin{array}{l}\text { Does our research } \\
\text { answer our question? }\end{array}$ & \multirow{2}{*}{$\begin{array}{l}\text { 5. Has that fixed the } \\
\text { problem? Why? } \\
\text { 6. Share findings, } \\
\text { even if there is no } \\
\text { final answer }\end{array}$} & \multirow{2}{*}{$\begin{array}{l}\text { 5. Has that fixed the } \\
\text { problem? Why? } \\
\text { 6. Share findings, } \\
\text { even if there is no } \\
\text { final answer }\end{array}$} & $\begin{array}{l}\text { 5. Is it clear that } \\
\text { fracking is bad overall? }\end{array}$ \\
\hline Step 6: Communicate & & & $\begin{array}{l}\text { 6. Share findings, } \\
\text { even if there is no } \\
\text { final answer }\end{array}$ \\
\hline & & Scaffolding & \\
\hline
\end{tabular}

Figure 1. The scientific method and examples. A framework for conducting scientific research is known as 'the scientific method'. All scientific studies follows these basic principles, but they are applicable to everyday activities and can be used to improve critical thinking. Examples show scaffolding technique to build up the levels of questioning. An important part is to understand that a negative result (e.g., not fully understanding a problem) is part of the process and can also be communicated.

By shifting the focus of the program to be about how we think about a subject rather than what we know, the material is applicable to everyone. Crucially, this creates an open structure, rewarding exploration and engagement over attainment, 60 suggested to be positive for all learners' self-esteem and progression (Ustun and Eryilmaz, 2018; Saloviita, 2020; Hornby, 2020).

\section{Accessible}

A key part of our course is that it is not taught in the standard education classrooms - an arena where many of the target students have had previous negative experiences. A common place to hold the course is in the library, which is not only sufficiently neutral ground to engage difficult to reach learners, but is also often carpeted to help with any sensory issues (Craswell et al., 2021). The threshold of a traditional classroom could be an unseen barrier to a student accessing education - a scenario that can be widely applied (e.g., students from low-economic backgrounds not wanting to engage in a outreach event held in a 14th Century Russell Group college).

Recent critical education (Greenstein, 2015) and critical disability (Goodley et al., 2018) literature references mainstream education 'norms' throughout the Global North. These norms, often internalised and maintained subconsciously, may subtly and or more explicitly celebrate an 'idealised' learner inhabiting a particular demographic, societal status, and learning profile; one who successfully progresses through a curriculum and pedagogy without requiring adaptation, who is not disabled or 


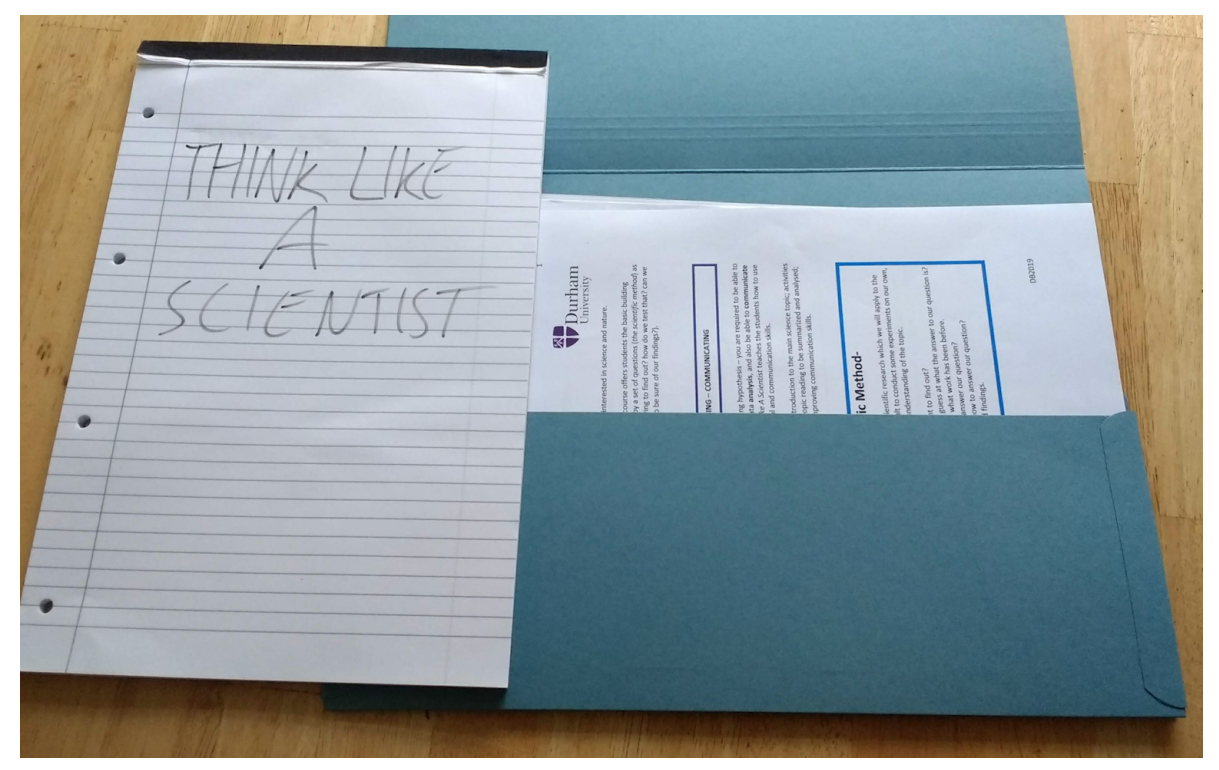

Figure 2. Accessible teaching. By making the equipment requirements for the course as basic as possible, there were no barriers to students accessing education resources. In Think Like A Scientist, only pen and paper were required.

neurodivergent, is without learning differences, and who effortlessly relates to the prevalent cultural meanings and values of their educators (Greenstein, 2015; Goodley et al., 2018).

A challenge here was to create course content that celebrated each student individually, rather than revert to our mainstream education norms. For a behavioural, cognitive, and emotional engagement to be achieved for all learners, an open and dynamic teacher-learner relationship must be fostered, built upon sensitive understanding (and adjustment) to a learner's needs and social contexts (Darling-Hammond et al., 2020). We applied this by taking into consideration a number of language points. Resources whilst teaching in prison are scarce, and often the only teaching aid available (apart from a pen and paper, Figure 2) is language (which turns out to be key). If the language used was terminology heavy or uses allegory, metaphor, or other forms of figurative or culturally specific language, this may have been difficult to process for many students. Potentially, this may have disadvantaged autistic students, or those with learning differences (Kalandadze et al., 2018). A positive step was to implement 'Plain Speak' English for universal accessibility, and then follow up with taking into consideration who and what was rewarded and prioritised in interactions with students (e.g., are we celebrating getting a correct answer or for asking a question of clarification?).

Furthermore, we taught practical examples of science in action to connect the student to the educational content through material relevant to cultural and life experiences (Cents-Boonstra et al., 2021). An example being discussing climate change with reference to the impact of food choices (as this is something that is done every day), or using a natural hazard that captured the public's attention to introduce plate tectonic processes (e.g., Iceland's Eyjafjallajökul volcanic eruption of 2010 or Hunga-Tonga eruption and tsunami of 2022). 
Many learners will continue to be excluded from learning opportunities in any classroom setting that doesn't take into consideration these accessibility issues, impacting not only their educational and professional progress but also their mental wealth and wellbeing (Tejerina-Arreal et al., 2020).

\section{Inclusive}

Although a certificate from a university is offered on completion of our course, there was no formal assessment strategy linked to the program. By breaking down the barrier of grading, an environment of open expression could begin to be created and allow for more potential students to engage. Through the main focus of the course being on how an individual's mind works to tackle a problem, we were able to tailor the learning experience and bring education to the student (von Stumm and Wertz, 2021).

Group discussion of opinions on topics are fundamental to the class (Pompa, 2013). In our course, students were often asked to give their thoughts on current topics (after reading recent research) with which there is no scientific consensus (e.g., should we colonize Mars? Is there life outside our Solar System?). As there is no right or wrong answer, the students were given a voice on cutting edge science - the impact on this on student's confidence can be significant.

Related to the previously mentioned 'stereotype threat' and 'minority stress' theories, this flattening of the power dynamic within the classroom meant that learning was made more inclusive and critical barriers to students' learning (which teachers may or may not be aware of) were removed.

\section{Encouragement}

From the classes taught in prison, not all students feel comfortable in writing down their thoughts and submitting work. However, for those that do, the work is 'marked' by highlighting the main points of their discussion and offering encouragement. Here, it was important to ignore spelling and grammar errors, and focus on the positive aspect of the student submitting thoughts and ideas (as discussed in Accessibility section).

Incidentally, by setting a task to express their thought process, rather than 'testable' questions, the work submitted was often really interesting. For those who submit, the feedback can be "like receiving a prize" as one student wrote in the course evaluation.

\section{Conclusions}

In this article, we have outlined our process for teaching STEM to students with unseen barriers to access their education pathway. Even though our course was designed with the restrictive and complex prison education system in mind, there is a wider application to this work specifically in settings where students are not engaging in formal education due to low confidence. Examples could be in running an outreach event or open day to students who encounter barriers due to their race, religion, disability, economic status, sexuality, gender or other intersecting cultural factors. 
https://doi.org/10.5194/egusphere-2022-16

Preprint. Discussion started: 4 March 2022

(c) Author(s) 2022. CC BY 4.0 License.

(c) (i)

We outline below a potential framework for breaking down educational barriers for students who (traditionally) do not engage:

- create a neutral classroom dynamic (in location and environment);

- have the class focus on dialogue;

- produce content that is relatable to everyday life;

- remove the grading structure (where possible);

- avoiding assumed previous knowledge;

- avoid asking explicitly worded questions;

- ask questions with no scientific consensus to generate discussion;

- implement clean 'Plain Speak' English;

- and emphasise encouragement when marking submitted work.

This framework produces dialogue focused course that is relatable, accessible, inclusive, and offers encouragement (RAIE method), which can allow students to build their confidence in STEM subjects.

Data availability. No primary data sets were used in producing this article.

Author contributions. P.J.H. and J.A.W. conceived, planned, and wrote the project.

Competing interests. The contact author has declared that neither they nor their co-authors have any competing interests.

Acknowledgements. P.J.H. and J.A.W. would like to thank the students of Think Like A Scientist for their participation in the course. The course developed from conversations and collaborations with a number of people across many partnerships, including Cell Block Science (Dr Mhairi Stewart), Inside-Out Prison Exchange Programme (Dr Hannah King, Dr Kate O’Brien, Dr Josie Phillips, and Lori Pompa), Dr

140 Rosie Reynolds, Dr Paula Street, Prof Danielle George, Dr Amber Lewis, Marianne Burrows, Bill Bryson, Dr Ivan Hill, Stuart Corbridge, Dr Andy Aplin, and Anna F. 
https://doi.org/10.5194/egusphere-2022-16

Preprint. Discussion started: 4 March 2022

(c) Author(s) 2022. CC BY 4.0 License.

(c) (i)

Financial support. The work on prison education was part of a project that previously received funding from the European Union's Horizon 2020 research and innovation program under the Marie Skłodowska-Curie Grant Agreement 749664 (P. J. Heron). A European Geosciences Union (EGU) Outreach Award and a British Geophysical Association Outreach Award was also used to fund the project. 
https://doi.org/10.5194/egusphere-2022-16

Preprint. Discussion started: 4 March 2022

(c) Author(s) 2022. CC BY 4.0 License.

(c) (i)

\section{References}

Angus, M., McDonald, T., Ormond, C., Rybarcyk, R., Taylor, A., and Winterton, A.: Trajectories of classroom behaviour and academic progress: A study of student engagement with learning, Mount Lawley. Western Australia: Edith Cowan University. Australian Education Union, 2008.

Billington, T.: Educational inclusion and critical neuroscience: friends or foes?, International Journal of Inclusive Education, 21, 866-880, https://doi.org/10.1080/13603116.2017.1283717, 2017.

Cents-Boonstra, M., Lichtwarck-Aschoff, A., Denessen, E., Aelterman, N., and Haerens, L.: Fostering student engagement with motivating teaching: an observation study of teacher and student behaviours, Research Papers in Education, 36, 754-779, https://doi.org/10.1080/02671522.2020.1767184, 2021.

Coates, S.: Unlocking Potential: A review of education in prison, London: Ministry of Justice, 2016.

Craswell, G., Dieleman, C., and Ghanouni, P.: An Integrative Review of Sensory Approaches in Adult Inpatient Mental Health: Implications for Occupational Therapy in Prison-Based Mental Health Services, Occupational Therapy in Mental Health, 37, 130-157, https://doi.org/10.1080/0164212X.2020.1853654, 2021.

Damasio, A. R.: The feeling of what happens: Body, emotion and the making of consciousness, Vintage, 2000.

Darling-Hammond, L., Flook, L., Cook-Harvey, C., Barron, B., and Osher, D.: Implications for educational practice of the science of learning and development, Applied Developmental Science, 24, 97-140, https://doi.org/10.1080/10888691.2018.1537791, 2020.

Davenport Huyer, L., Callaghan, N. I., Dicks, S., Scherer, E., Shukalyuk, A. I., Jou, M., and Kilkenny, D. M.: Enhancing senior high school student engagement and academic performance using an inclusive and scalable inquiry-based program, npj Science of Learning, 5, 17, https://doi.org/10.1038/s41539-020-00076-2, 2020.

Dowey, N., Barclay, J., Fernando, B., Giles, S., Houghton, J., Jackson, C., Khatwa, A., Lawrence, A., Mills, K., Newton, A., Rogers, S., and Williams, R.: A UK perspective on tackling the geoscience racial diversity crisis in the Global North, Nature Geoscience, 14, 256-259, https://doi.org/10.1038/s41561-021-00737-w, 2021.

Geib, C. F., Chapman, J. F., D’Amaddio, A. H., and Grigorenko, E. L.: The education of juveniles in detention: Policy considerations and infrastructure development, Learning and Individual Differences, 21, 3-11, https://doi.org/https://doi.org/10.1016/j.lindif.2010.05.002, 2011.

170 Goodley, D., Lawthorn, R., Liddiard, K., and Cole, K. R.: Critical disability studies, p. 491-595, PALGRAVE MACMILLAN, 2018.

Greenstein, A.: Radical inclusive education: Disability, teaching and struggles for liberation, Routledge, 2015.

Heron, P. J.: Unlocking the doors to education for prisoners, Astronomy \& Geophysics, 60, 5.13-5.13, https://doi.org/10.1093/astrogeo/atz173, 2019.

Heron, P. J.: Teaching geoscience in prison, Nature Reviews Earth \& Environment, 1, 88-88, https://doi.org/10.1038/s43017-020-0020-7, 2020.

Holmes, K., Gore, J., Smith, M., and Lloyd, A.: An Integrated Analysis of School Students'Aspirations for STEM Careers: Which Student and School Factors Are Most Predictive?, International Journal of Science and Mathematics Education, 16, 655-675, https://doi.org/10.1007/s10763-016-9793-z, 2018.

Hornby, G.: The Necessity for Coexistence of Equity and Excellence in Inclusive and Special Education, Oxford University Press, 2020. 
https://doi.org/10.5194/egusphere-2022-16

Preprint. Discussion started: 4 March 2022

(c) Author(s) 2022. CC BY 4.0 License.

(c) (i)

Kalandadze, T., Norbury, C., Nærland, T., and Næss, K.-A. B.: Figurative language comprehension in individuals with autism spectrum disorder: A meta-analytic review, Autism : the international journal of research and practice, 22, 99-117, https://doi.org/10.1177/1362361316668652, 2018.

King, H., Measham, F., and O’Brien, K.: Building Bridges Across Diversity: Utilising the Inside-Out prison exchange programme to promote egalitarian higher education community within three UK prisons, International Journal of Bias, Identity and Diversity in Education, 4, 66-81, 2018.

Legault, L., Green-Demers, I., and Pelletier, L.: Why do high school students lack motivation in the classroom? Toward an understanding of academic motivation and the role of social support, Journal of Educational Psychology, 98, 567-582, 2006.

Meyer, I. H.: Minority stress and mental health in gay men, J Health Soc Behav., 36, 38-56, 1995.

O’Brien, K., King, H., Phillips, J., Dalton, Kath, and Phoenix: “Education as the practice of freedom?” - prison education and the pandemic, Educational Review, 0, 1-19, https://doi.org/10.1080/00131911.2021.1996335, 2021.

Parker, M. N. and Jones, R. T.: Minority Status Stress: Effect on the Psychological and Academic Functioning of African-American Students, Journal of Gender, Culture and Health, 4, 61-82, 1999.

Pennington, C. R., Heim, D., Levy, A., and Larkin, D.: Twenty Years of Stereotype Threat Research: A Review of Psychological Mediators, PLoS One, 11, 797-811, https://doi.org/10.1371/journal.pone.0146487, 2016.

Pompa, L.: One Brick at a Time: The Power and Possibility of Dialogue Across the Prison Wall, The Prison Journal, 93, 127-134, https://doi.org/10.1177/0032885512472479, 2013.

Rogers, L., Hurry, J., Simonot, M., and Wilson, A.: The aspirations and realities of prison education for under-25s in the London area, London Review of Education, 12, 184-196, 2014.

Saloviita, T.: Attitudes of Teachers Towards Inclusive Education in Finland, Scandinavian Journal of Educational Research, 64, 270-282, https://doi.org/10.1080/00313831.2018.1541819, 2020.

Statistics Canada: Youth in Translation Survey, Statistics Canada, 2002.

Steele, C. M. and Aronson, J.: Stereotype threat and the intellectual test performance of African Americans, Journal of personality and social psychology, 69, 797-811, https://doi.org/10.1037//0022-3514.69.5.797, 1995.

Tejerina-Arreal, M., Parker, C., Paget, A., Henley, W., Logan, S., Emond, A., and Ford, T.: Child and adolescent mental health trajectories in relation to exclusion from school from the Avon Longitudinal Study of Parents and Children, Child and Adolescent Mental Health, 25, 217-223, https://doi.org/https://doi.org/10.1111/camh.12367, 2020.

Ustun, U. and Eryilmaz, A.: Analysis of Finnish Education System to Question the Reasons behind Finnish Success in PISA, Online Submission, 2, 93-114, 2018.

von Stumm, S. and Wertz, J.: Who's learning? Using within-family studies to understand personalized learning, npj Science of Learning, 6, https://doi.org/https://doi.org/10.1038/s41539-020-00082-4, 2021. 